\title{
VALUATION OF THE NUTRITIONAL MATRIX BY PHYTASE AND SOY GUM IN THE DIET FORMULATION FOR BROILER CHICKENS ${ }^{1}$
}

\author{
LUIZ GUSTAVO NASCIMENTO ROSTICHELLI ${ }^{2}$, ANTONIO CARLOS DE LAURENTIZ ${ }^{*}$, ROSEMEIRE DA SILVA \\ FILARDI $^{3}$, ROSEMARY PEREIRA DE PEDRO SOUZA ${ }^{3}$, MATHEUS SOUSA DE PAULA CARLIS ${ }^{4}$
}

\begin{abstract}
The study was carried out with the objective of evaluating whether the valorisation of the nutritional matrix by the addition of the enzyme phytase and soy gum, in isolation or in association in the formulation of broiler chicken diets compromises the performance in the phase of 7 to 42 days of age and can be economically viable. Seven hundred 7-day-old male Cobb 500 broiler chicks were distributed in a completely randomised design consisting of seven treatments and five replications of 20 birds. The treatments consisted of a standard diet and six other diets whose matrix values of phytase and gum were valued, either alone or in combination, in the formulation of the diets. The individual valuation of the nutritional matrix of the phytase and soy gum in the formulation of feed for broiler chickens did not compromise the zootechnical performance of the chickens; however, only the valuation with phytase proved economically viable, since the inclusion of the gum and its valuation did not contribute to a reduction in the production cost or gross margin compared to a standard diet.
\end{abstract}

Keywords: Additive. Available phosphorus. Emulsifie. Lecithin. Metabolisable energy.

\section{VALORAÇÃO DA MATRIZ NUTRICIONAL DA FITASE E DA GOMA DE SOJA NA FORMULAÇÃO DE RAÇÕES PARA FRANGOS DE CORTE}

\begin{abstract}
RESUMO - O estudo foi realizado com o objetivo de avaliar se a valoração da matriz nutricional da enzima fitase e da goma de soja, de forma isoladas ou associadas, na formulação de rações de frango de corte compromete o desempenho na fase de 7 a 42 dias de idade e pode ser viável economicamente. Setecentos pintos machos de corte da linhagem Cobb 500 com 7 dias de idade foram distribuídas em um delineamento inteiramente casualizado, composto por 7 tratamentos e 5 repetições de 20 aves. Em cada fase os tratamentos consistiram em uma dieta padrão e mais seis dietas cujas matrizes nutricionais da enzima fitase e da goma, de forma isolada ou associadas, foram valorizadas na formulação das rações. A valorização individual da matriz nutricional da enzima fitase e da goma de soja, na formulação de ração para frango de corte, não comprometeu o desempenho zootécnico dos frangos, entretanto apenas a valorização da fitase mostrou-se economicamente viável, uma vez que inclusão da goma e sua valorização não contribuiu para a redução no custo de produção ou margem bruta em relação a uma dieta padrão.
\end{abstract}

Palavras-chave: Aditivos. Emulsificante. Energia metabolizável. Fósforo disponível. Lecitina.

\footnotetext{
${ }^{*}$ Corresponding author

${ }^{1}$ Received for publication in 08/13/2019; accepted in 07/24/2020.

Paper extracted from the master dissertation of the first author.

${ }^{2}$ State Technical School "Sebastiana Augusta de Moraes", Centro Estadual de Educação Tecnológica Paula Souza, Andradina, SP, Brazil; gustavorostichelli@yahoo.com.br - ORCID: 0000-0001-6199-8933.

${ }^{3}$ Department of Biology and Zootechnic, Universidade Estadual Paulista "Júlio de Mesquita Filho", Ilha Solteira, SP, Brazil; antonio.laurentiz@unesp.br - ORCID: 0000-0001-9553-730X; rosemeire.filardi@unesp.br - ORCID: 0000-0003-1271-6092; rosemaryppsouza@gmail.com - ORCID: 0000-0002-7165-3290.

${ }^{4}$ Department of Animal Science, College of Agriculture "Luiz de Queiroz", Universidade de São Paulo, Piracicaba, SP, Brazil; dicarlis@usp.br-ORCID: 0000-0003-2641-5987.
} 


\section{INTRODUCTION}

The advancements in poultry production, mainly in the production of broiler chickens, demonstrates the importance of research in the search for alternatives to reduce feed costs, since these represent around $71.56 \%$ of production costs (EMBRAPA, 2020).

However, the main challenge of nutritionists is to promote the reduction of production costs, coupled with the mitigation of waste pollutants and the promotion of health and animal welfare. In this way, many studies aim to evaluate ways of optimising the use of raw materials, and co-products and by-products from industry. A promising method to achieve these goals and one that has received great attention in recent years is the use of additives such as exogenous enzymes and emulsifiers (GÁLIK et al., 2019).

Generally, poultry rations are basically formulated with corn and soybean meal, ingredients whose phosphorus content has only $33 \%$ availability. (ROSTAGNO et al., 2011). The unavailability of almost $2 / 3$ of the phosphorus contained in ingredients of plant origin is because it is bonded to inositol, forming phytic acid or inositol hexaphosphate, which can form nutritionally important organic mineral complexes and represents one of the main anti-nutritional factors that affect nutrient availability for monogastric animals (COWIESON; WILCOCK; BEDFORD, 2011). An alternative to increase the availability of phosphorus and other complexed nutrients in the phytic acid molecule and the release of energy is the inclusion of exogenous enzymes in the feed, such as microbial phytases (MANOBHAVAN et al., 2015; WU et al., 2015).

Other prominent additives used to increase the efficiency of the use of lipids, and therefore energy in the feed, are emulsifiers (BORSATTI et al., 2018; VIÑADO et al., 2019). One of the emulsifying compounds used in diets is soy lecithin (ZHANG et al., 2011), a co-product obtained in the production of soy oil by the process called degumming, which consists of the extraction of phospholipids from soy gum by adding water at a temperature of $60-90{ }^{\circ} \mathrm{C}$ under constant pressure (ARAÚJO, 2008).

The process of obtaining lecithin from soy gum for use in animal feed could be eliminated by using soy gum directly as an emulsifier, since it is a source of lecithin, but studies are still limited (AKECHI, 2015; SOUZA et al., 2019). Just as the enzyme phytase has a nutritional matrix recommended by the manufacturers, a nutritional matrix for soy gum could be explored, with valuation of its energy content (MELLO, 2017).

This study was carried out with the objective of evaluating whether valuation of the nutritional matrix by the enzyme and soy gum, in isolated or associated form, in the formulation of broiler diets compromises the performance of broilers in the phase from 7 to 42 days old and is economically viable.

\section{MATERIAL AND METHODS}

The experiment was conducted in the Poultry Sector of the Faculty of Engineering - Unesp - Ilha Solteira Campus, with the experimental procedures being approved by the Institution's Ethics Committee on the Use of Animals ( $n^{\circ}$ 20/2016 CEUA).

One-day-old Cobb 500 male broilers were allocated in a conventional broiler chicken house with an experimental period from 7 to 42 days old. The experimental housing was of the conventional type and consisted of a ceramic tile cover, concrete floor, $0.30-\mathrm{m}$ high side walls complete with wire mesh up to the roof $3.20 \mathrm{~m}$ in height with a movable external curtain, divided into $354-\mathrm{m}^{2}$ boxes separated by $0.70-\mathrm{m}$ high screens.

At 7 days of age, 700 birds were selected according to body weight $(139 \pm 14 \mathrm{~g})$ and distributed in a completely randomised design consisting of seven treatments and five repetitions of 20 birds. The seven treatments were represented by a standard diet and six different diets in each of the breeding phases ( 7 to 21,22 to 35 and 36 to 42 days of age), which were formulated by the valuation of the phytase nutritional matrix (metabolisable energy (ME), available phosphorus and calcium), soy gum nutritional matrix (ME) or a nutritional matrix of both ingredients. Therefore, the treatments were designated as follows:

Control diet (CON), without the inclusion of phytase or soy gum and with the standardised nutritional levels (SN) for the phase;

Feed formulated valuing the nutritional matrix of phytase and with its inclusion $(\mathrm{SN}+\mathrm{P})$; and

Feed formulated valuing the nutritional matrix of phytase but without its inclusion in the mix (SN-P), being replaced by inert material and therefore with an average reduction of $1.60 \%$ in $\mathrm{ME}$, $19.18 \%$ in $\mathrm{Ca}$ and $32.38 \%$ at aP levels;

Feed formulated valuing the nutritional matrix of soy gum and with its inclusion $(\mathrm{SN}+\mathrm{G})$;

Feed formulated valuing the nutritional matrix of soy gum but without its inclusion in the mix (RN-G), being replaced by inert material with an average reduction of $7.06 \%$ in $\mathrm{ME}$;

Feed formulated valuing the association of the nutritional matrix of phytase and soy gum, containing both ingredients $(\mathrm{SN}+\mathrm{P}+\mathrm{G})$;

Feed formulated valuing the association of the nutritional matrix of phytase and soy gum but without the addition of these ingredients in the mix (RN-P-G), which were replaced by inert material, which produced average reductions of $8.66 \%$ in $\mathrm{ME}$, $19.18 \%$ in $\mathrm{Ca}$ and $32.38 \%$ at aP levels. 
The phytase enzyme used was Ronozyme Hyphos ${ }^{\circledR} 10,000$ FTU, with the inclusion of 1,000 FTU/kg of diet (100 g/ton), whose nutritional matrix for the formulation of the diet was $500,000 \mathrm{kcal} \mathrm{ME}$, $1,168 \%$ of aP and $1,420 \% \mathrm{Ca}$, therefore contributing $50 \mathrm{kcal} / \mathrm{kg}, \quad 0.1168 \%$ aP $0.142 \% \quad \mathrm{Ca}$. In the nutritional matrix of soy gum the value of 11,000 $\mathrm{kcal} \mathrm{ME} / \mathrm{kg}$ was used, a value estimated by Mello (2017) with the inclusion of $2 \%$ of this co-product in the feed. The inclusion of $2 \%$ of soy gum contributed $220 \mathrm{kcal} / \mathrm{kg}$ of diet.

The experimental diets were formulated based on corn and soybean meal (Tables 1, 2 and 3), following the composition of the ingredients presented by Rostagno et al. (2011) and the nutritional recommendations indicated by the Cobb 500 lineage manual for each breeding stage.

In the present study, the 1- to 7-day old phase was not evaluated because it is a delicate phase to expose birds to reduced $\mathrm{Ca}$, aP and energy levels.

The parameters of zootechnical performance, feed intake, weight gain and feed conversion ratio were evaluated in the phases from 7 to $21 \mathrm{~d}, 22$ to $35 \mathrm{~d}, 36$ to $42 \mathrm{~d}$ and in the total phase from 7 to $42 \mathrm{~d}$ of age.

In the economic analysis, the prices of ingredients used in the diets and the commercialisation value per $\mathrm{kg}$ of live chicken were those current in the first half of 2020 in the state of São Paulo, with the cost of each diet presented in the feed composition tables in each phase (Tables 1, 2 and 3). As soy gum is still a little-used ingredient in animal feed, the availability of its market price was restricted. In this way, the price of soy gum used in the formulation of animal feed was compared to the price of soy oil. Based on the average feed cost of each phase, the average cost of the diet was determined and represented the cost of food for the production of $1 \mathrm{~kg}$ of live chicken ( $\mathrm{R} / \mathrm{kg} \mathrm{LC})$, and the gross commercialisation margin (GCM) was calculated considering the total weight gain (TWG), total feed consumption (TFC), price per $\mathrm{kg}$ of live chicken (PLC) and cost per $\mathrm{kg}$ of diet (CD), according to the formula proposed by Trevisan (2013):

$$
G C M=\frac{T W G}{T F C} \times \frac{P L C}{C D}
$$

Table 1. Percentage composition of ingredients and nutritional composition calculated from experimental diets in the initial phase from 7 to 21 days of age.

\begin{tabular}{cccccccc}
\hline \multirow{2}{*}{ Ingredients (\%) } & \multicolumn{4}{c}{ Phytase Matrix } & \multicolumn{2}{c}{ Gum Matrix } & \multicolumn{2}{c}{ Phytase and Gum Matrix } \\
\cline { 2 - 7 } & CON & SN+P & RN-P & SN+G & RN-G & SN+P+G & RN-P-G \\
\hline Corn & 54.07 & 56.44 & 56.44 & 55.27 & 55.27 & 57.1 & 57.1 \\
Soybean meal 46\% & 36.07 & 35.67 & 35.67 & 35.78 & 35.78 & 35.46 & 35.46 \\
Limestone & 0.89 & 0.93 & 0.93 & 0.93 & 0.93 & 0.97 & 0.97 \\
Dicalcium phosphate & 1.56 & 0.93 & 0.93 & 1.49 & 1.49 & 0.86 & 0.86 \\
Soybean oil & 4.08 & 2.71 & 2.71 & 1.19 & 1.19 & 0.00 & 0.00 \\
Salt & 0.509 & 0.509 & 0.509 & 0.508 & 0.508 & 0.507 & 0.507 \\
Mineral and vitamin supplement* & 0.600 & 0.600 & 0.600 & 0.600 & 0.600 & 0.600 & 0.600 \\
DL-methionine & 0.029 & 0.028 & 0.027 & 0.029 & 0.029 & 0.028 & 0.028 \\
L-lysine & 0.186 & 0.194 & 0.194 & 0.193 & 0.193 & 0.199 & 0.199 \\
Phytase & 0.000 & 0.010 & 0.000 & 0.000 & 0.000 & 0.010 & 0.000 \\
Soy gum & 0.000 & 0.000 & 0.000 & 2.000 & 0.000 & 2.000 & 0.000 \\
Inert material & 2.006 & 1.979 & 1.990 & 2.010 & 4.010 & 2.266 & 4.276 \\
\hline Diet cost (R\$/kg) & 1.442 & 1.391 & 1.384 & 1.411 & 1.333 & 1.363 & 1.279 \\
\hline ME (kcal/kg) & 3,000 & 3,000 & 2,950 & 3,000 & 2,780 & 3,000 & 2,730 \\
Crude protein (\%) & 21.00 & 21.00 & 21.00 & 21.00 & 21.00 & 21.00 & 21.00 \\
Calcium (\%) & 0.82 & 0.82 & 0.68 & 0.82 & 0.82 & 0.82 & 0.68 \\
Available phosphorus (\%) & 0.40 & 0.40 & 0.28 & 0.40 & 0.40 & 0.40 & 0.28 \\
\hline
\end{tabular}

$\mathrm{CON}=$ recommended levels of $\mathrm{ME}, \mathrm{aP}$ and $\mathrm{Ca} ; \mathrm{SN}+\mathrm{P}=$ enhancement of the phytase nutritional matrix and its inclusion; $\mathrm{RN}-\mathrm{P}=$ enhancement of the phytase nutritional matrix, without its inclusion and reduction of $\mathrm{ME}$, aP and $\mathrm{Ca}$; $\mathrm{SN}+\mathrm{G}=\mathrm{valorisation}$ of the nutritional matrix with soy gum by its inclusion; $\mathrm{RN}-\mathrm{G}=$ valorisation of the gum's nutritional matrix, without its inclusion and reduction of $\mathrm{ME} ; \mathrm{SN}+\mathrm{P}+\mathrm{G}=$ enhancement of the nutritional matrix of phytase and gum with the inclusion of both; RN-P-G = enhancement of the nutritional matrix of phytase and gum, without including both and with a reduction in $\mathrm{ME}$, aP and Ca.

*Mineral and vitamin supplement, nutrient levels per kilogram of feed: Vit. A 10,020 UI, Vit.D ${ }_{3} 2,010$ UI, Vit. E 15 mg, Vit. $K_{3} 2.50$ mg, Vit. $B_{1} 1.5 \mathrm{mg}$, Vit. $B_{2} 5.01 \mathrm{mg}, B_{6} 1.5 \mathrm{mg}$, Vit. $B_{12} 12 \mu \mathrm{g}$, Folic acid $0.6 \mathrm{mg}$, Biotin $0.05 \mathrm{mg}$, Niacin $35 \mathrm{mg}$, Calcium Pantothenate $11.22 \mathrm{mg}$, Copper $6 \mathrm{mg}$, Cobalt $0.10 \mathrm{mg}$, Iodine $1.02 \mathrm{mg}$, Iron $50 \mathrm{mg}$, Manganese $65 \mathrm{mg}$, Zinc $45 \mathrm{mg}$, Selenium $0.21 \mathrm{mg}$, Choline Chloride $(50 \%) 700 \mathrm{mg}$, Coccidicide $80 \mathrm{mg}$, Performance enhancer $80 \mathrm{mg}$, Antioxidant $12 \mathrm{mg}$. 
Table 1. Continuation.

\begin{tabular}{cccccccc}
\hline \multirow{2}{*}{ Ingredients (\%) } & \multicolumn{4}{c}{ Phytase Matrix } & \multicolumn{2}{c}{ Gum Matrix } & \multicolumn{2}{c}{ Phytase and Gum Matrix } \\
\cline { 2 - 8 } & CON & SN+P & RN-P & SN+G & RN-G & SN+P+G & RN-P-G \\
\hline Total phosphorus (\%) & 0.63 & 0.50 & 0.50 & 0.63 & 0.63 & 0.50 & 0.50 \\
Fat (\%) & 6.41 & 5.12 & 5.12 & 3.59 & 3.59 & 2.46 & 2.46 \\
Digestible lysine (\%) & 1.17 & 1.17 & 1.17 & 1.17 & 1.17 & 1.17 & 1.17 \\
Digestible methionine (\%) & 0.46 & 0.46 & 0.46 & 0.46 & 0.46 & 0.46 & 0.46 \\
Sodium (\%) & 0.22 & 0.22 & 0.22 & 0.22 & 0.22 & 0.22 & 0.22 \\
\hline
\end{tabular}

$\mathrm{CON}=$ recommended levels of $\mathrm{ME}, \mathrm{aP}$ and $\mathrm{Ca} ; \mathrm{SN}+\mathrm{P}=$ enhancement of the phytase nutritional matrix and its inclusion; $\mathrm{RN}-\mathrm{P}=$ enhancement of the phytase nutritional matrix, without its inclusion and reduction of $\mathrm{ME}$, aP and $\mathrm{Ca} ; \mathrm{SN}+\mathrm{G}=$ valorisation of the nutritional matrix with soy gum by its inclusion; $\mathrm{RN}-\mathrm{G}=$ valorisation of the gum's nutritional matrix, without its inclusion and reduction of $\mathrm{ME} ; \mathrm{SN}+\mathrm{P}+\mathrm{G}=$ enhancement of the nutritional matrix of phytase and gum with the inclusion of both; RN-P-G = enhancement of the nutritional matrix of phytase and gum, without including both and with a reduction in $\mathrm{ME}$, aP and $\mathrm{Ca}$.

*Mineral and vitamin supplement, nutrient levels per kilogram of feed: Vit. A 10,020 UI, Vit.D 2 2,010 UI, Vit. E 15 mg, Vit. K 2.50 $\mathrm{mg}$, Vit. $\mathrm{B}_{1} 1.5 \mathrm{mg}$, Vit. $\mathrm{B}_{2} 5.01 \mathrm{mg}, \mathrm{B}_{6} 1.5 \mathrm{mg}$, Vit. B $12,12 \mu \mathrm{g}$, Folic acid $0.6 \mathrm{mg}$, Biotin $0.05 \mathrm{mg}$, Niacin $35 \mathrm{mg}$, Calcium Pantothenate $11.22 \mathrm{mg}$, Copper $6 \mathrm{mg}$, Cobalt $0.10 \mathrm{mg}$, Iodine $1.02 \mathrm{mg}$, Iron $50 \mathrm{mg}$, Manganese $65 \mathrm{mg}$, Zinc $45 \mathrm{mg}$, Selenium $0.21 \mathrm{mg}$, Choline Chloride (50\%) $700 \mathrm{mg}$, Coccidicide $80 \mathrm{mg}$, Performance enhancer $80 \mathrm{mg}$, Antioxidant $12 \mathrm{mg}$.

Table 2. Percentage composition of ingredients and nutritional composition calculated from experimental diets in the initial phase from 22 to 35 days of age.

\begin{tabular}{cccccccc}
\hline \multirow{2}{*}{ Ingredients (\%) } & \multicolumn{4}{c}{ Phytase Matrix } & \multicolumn{2}{c}{ Gum Matrix } & \multicolumn{2}{c}{ Phytase and Gum Matrix } \\
\cline { 2 - 7 } & $\mathrm{CON}$ & $\mathrm{SN}+\mathrm{P}$ & $\mathrm{RN}-\mathrm{P}$ & $\mathrm{SN}+\mathrm{G}$ & $\mathrm{RN}-\mathrm{G}$ & $\mathrm{SN}+\mathrm{P}+\mathrm{G}$ & $\mathrm{RN}-\mathrm{P}-\mathrm{G}$ \\
\hline Corn & 57.80 & 60.18 & 60.18 & 59.01 & 59.01 & 61.38 & 61.38 \\
Soybean meal 46\% & 31.11 & 30.70 & 30.70 & 30.81 & 30.81 & 30.40 & 30.40 \\
Limestone & 0.83 & 0.86 & 0.86 & 0.87 & 0.87 & 0.91 & 0.91 \\
Dicalcium phosphate & 1.33 & 0.70 & 0.70 & 1.27 & 1.27 & 0.63 & 0.63 \\
Soybean oil & 5.62 & 4.25 & 4.25 & 2.74 & 2.74 & 1.36 & 1.36 \\
Salt & 0.459 & 0.458 & 0.458 & 0.458 & 0.458 & 0.458 & 0.458 \\
Mineral and vitamin supplement\% & 0.600 & 0.600 & 0.600 & 0.600 & 0.600 & 0.600 & 0.600 \\
DL-methionine & 0.023 & 0.021 & 0.021 & 0.022 & 0.022 & 0.021 & 0.021 \\
L-lysine & 0.221 & 0.228 & 0.228 & 0.228 & 0.228 & 0.235 & 0.235 \\
Phytase & 0.000 & 0.010 & 0.000 & 0.000 & 0.000 & 0.010 & 0.000 \\
Soy gum & 0.000 & 0.000 & 0.000 & 2.000 & 0.000 & 2.000 & 0.000 \\
Inert material & 2.007 & 1.993 & 2.003 & 1.992 & 3.992 & 1.996 & 4.006 \\
\hline Diet cost (R\$/kg) & 1.422 & 1.370 & 1.363 & 1.391 & 1.313 & 1.338 & 1.254 \\
\hline ME (kcal/kg) & & Calculated nutrients & & & & 2,880 \\
Crude protein (\%) & 3,150 & 3,150 & 3,100 & 3,150 & 2,930 & 3,150 & 19.00 \\
Calcium (\%) & 19.00 & 19.00 & 19.00 & 19.00 & 19.00 & 19.00 & 0.59 \\
Available phosphorus (\%) & 0.73 & 0.73 & 0.59 & 0.73 & 0.73 & 0.73 & 0.24 \\
Total phosphorus (\%) & 0.35 & 0.35 & 0.24 & 0.35 & 0.35 & 0.35 & 0.45 \\
Fat (\%) & 0.56 & 0.45 & 045 & 0.56 & 0.56 & 0.45 & 3.89 \\
Digestible lysine (\%) & 8.00 & 6.71 & 6.71 & 5.17 & 5.17 & 3.89 & 1.08 \\
Digestible methionine (\%) & 1.08 & 1.08 & 1.08 & 1.08 & 1.08 & 1.08 & 0.43 \\
Sodium (\%) & 0.43 & 0.43 & 0.43 & 0.43 & 0.43 & 0.43 & 0.20 \\
\hline & 0.20 & 0.20 & 0.20 & 0.20 & 0.20 & 0.20 & \\
\hline & & & & & & & \\
\hline
\end{tabular}

$\mathrm{CON}=$ recommended levels of $\mathrm{ME}, \mathrm{aP}$ and $\mathrm{Ca} ; \mathrm{SN}+\mathrm{P}=$ enhancement of the phytase nutritional matrix and its inclusion; $\mathrm{RN}-\mathrm{P}=$ enhancement of the phytase nutritional matrix, without its inclusion and reduction of $\mathrm{ME}, \mathrm{aP}$ and $\mathrm{Ca} ; \mathrm{SN}+\mathrm{G}=$ valorisation of the nutritional matrix of soy gum by its inclusion; $\mathrm{RN}-\mathrm{G}=$ valorisation of the gum's nutritional matrix, without its inclusion and reduction of ME; $\mathrm{SN}+\mathrm{P}+\mathrm{G}=$ enhancement of the nutritional matrix of phytase and gum with the inclusion of both; RN-P-G = enhancement of the nutritional matrix of phytase and gum, without including both and with a reduction in $\mathrm{ME}, \mathrm{aP}$ and $\mathrm{Ca}$.

*Mineral and vitamin supplement, levels of nutrients per kilogram of feed: Vit. A 8,010 IU, Vit.D3 1,800 IU, Vit. And 12 mg, Vit. K3 $2 \mathrm{mg}$, Vit. B1 $1 \mathrm{mg}$, Vit. B2 $4.02 \mathrm{mg}$, B6 $1.02 \mathrm{mg}$, Vit. B12 $10.02 \mu \mathrm{g}$, Folic Acid $0.402 \mathrm{mg}$, Biotin $0.042 \mathrm{mg}$, Niacin $28.02 \mathrm{mg}$, Calcium Pantothenate $11.22 \mathrm{mg}$, Copper $6 \mathrm{mg}$, Cobalt $0.102 \mathrm{mg}$, Iodine $1.02 \mathrm{mg}$, Iron $50 \mathrm{mg}$, Manganese $65 \mathrm{mg}$, Zinc $45 \mathrm{mg}$, Selenium $0.21 \mathrm{mg}$, Choline Chloride (50\%) $500 \mathrm{mg}$, Coccidicide $60 \mathrm{mg}$, Performance enhancer $60 \mathrm{mg}$, Antioxidant $12 \mathrm{mg}$. 
Table 3. Percentage composition of ingredients and nutritional composition calculated from experimental diets in the initial phase from 36 to 42 days of age.

\begin{tabular}{|c|c|c|c|c|c|c|c|}
\hline \multirow{2}{*}{ Ingredients $(\%)$} & \multicolumn{3}{|c|}{ Phytase Matrix } & \multicolumn{2}{|c|}{ Gum Matrix } & \multicolumn{2}{|c|}{ Phytase and Gum Matrix } \\
\hline & $\mathrm{CON}$ & $\mathrm{SN}+\mathrm{P}$ & RN-P & $\mathrm{SN}+\mathrm{G}$ & $\mathrm{RN}-\mathrm{G}$ & $\mathrm{SN}+\mathrm{P}+\mathrm{G}$ & $\mathrm{RN}-\mathrm{P}-\mathrm{G}$ \\
\hline Corn & 61.14 & 63.48 & 63.48 & 62.31 & 62.31 & 64.68 & 64.68 \\
\hline Soybean meal $46 \%$ & 28.36 & 27.96 & 27.96 & 28.07 & 28.07 & 27.66 & 27.66 \\
\hline Limestone & 0.76 & 0.80 & 0.80 & 0.81 & 0.81 & 0.84 & 0.84 \\
\hline Dicalcium phosphate & 1.09 & 0.45 & 0.45 & 1.02 & 1.02 & 0.39 & 0.39 \\
\hline Soybean oil & 5.62 & 4.25 & 4.25 & 2.74 & 2.74 & 1.36 & 1.36 \\
\hline Salt & 0.446 & 0.445 & 0.445 & 0.446 & 0.446 & 0.445 & 0.445 \\
\hline Mineral and vitamin supplement* & 0.300 & 0.300 & 0.300 & 0.300 & 0.300 & 0.300 & 0.300 \\
\hline DL-methionine & 0.089 & 0.089 & 0.089 & 0.089 & 0.089 & 0.088 & 0.088 \\
\hline L-lysine & 0.200 & 0.221 & 0.221 & 0.220 & 0.220 & 0.223 & 0.223 \\
\hline Phytase & 0.000 & 0.010 & 0.000 & 0.000 & 0.000 & 0.010 & 0.000 \\
\hline Soy gum & 0.000 & 0.000 & 0.000 & 2.000 & 0.000 & 2.000 & 0.000 \\
\hline Inert & 1.995 & 1.995 & 2.005 & 1.995 & 3.995 & 2.004 & 4.014 \\
\hline \multirow[t]{2}{*}{ Diet cost $(\mathrm{R} \$ / \mathrm{kg})$} & 1.347 & 1.296 & 1.289 & 1.317 & 1.239 & 1.264 & 1.179 \\
\hline & \multicolumn{7}{|c|}{ Calculated nutrients } \\
\hline $\mathrm{ME}(\mathrm{kcal} / \mathrm{kg})$ & 3,200 & 3,200 & 3,150 & 3,200 & 2,980 & 3,200 & 2,930 \\
\hline Crude protein $(\%)$ & 18.00 & 18.00 & 18.00 & 18.00 & 18.00 & 18.00 & 18.00 \\
\hline Calcium (\%) & 0.64 & 0.64 & 0.50 & 0.64 & 0.64 & 0.64 & 0.50 \\
\hline Available phosphorus (\%) & 0.30 & 0.30 & 0.19 & 0.30 & 0.30 & 0.30 & 0.19 \\
\hline Total phosphorus (\%) & 0.51 & 0.40 & 0.40 & 0.51 & 0.51 & 0.40 & 0.40 \\
\hline Fat (\%) & 8.07 & 6.79 & 6.79 & 5.25 & 5.25 & 3.97 & 3.97 \\
\hline Digestible lysine (\%) & 1.01 & 1.01 & 1.01 & 1.01 & 1.01 & 1.01 & 1.01 \\
\hline Digestible methionine (\%) & 0.41 & 0.41 & 0.41 & 0.41 & 0.41 & 0.41 & 0.41 \\
\hline Sodium (\%) & 0.19 & 0.19 & 0.19 & 0.19 & 0.19 & 0.19 & 0.19 \\
\hline
\end{tabular}

$\mathrm{CON}=$ recommended levels of $\mathrm{ME}, \mathrm{aP}$ and $\mathrm{Ca} ; \mathrm{SN}+\mathrm{P}=$ enhancement of the phytase nutritional matrix and its inclusion; $\mathrm{RN}-\mathrm{P}=$ enhancement of the phytase nutritional matrix, without its inclusion and reduction of $\mathrm{ME}$, aP and $\mathrm{Ca}$; $\mathrm{SN}+\mathrm{G}=\mathrm{valorisation}$ of the nutritional matrix of soy gum by its inclusion; $\mathrm{RN}-\mathrm{G}=$ valorisation of the gum's nutritional matrix, without its inclusion and reduction of $\mathrm{ME} ; \mathrm{SN}+\mathrm{P}+\mathrm{G}=$ enhancement of the nutritional matrix of phytase and gum with the inclusion of both; RN-P-G = enhancement of the nutritional matrix of phytase and gum, without including both and with a reduction in $\mathrm{ME}$, aP and $\mathrm{Ca}$.

*Mineral and vitamin supplement, levels of nutrients per kilogram of feed: Vit. A 5,010 IU, Vit.D3 1,005 IU, Vit. E 7 mg, Vit. K3 $1.2 \mathrm{mg}$, Vit. B1 $0.3 \mathrm{mg}$, Vit. B2 $2.4 \mathrm{mg}$, B6 $0.6 \mathrm{mg}$, Vit. B12 $6 \mu \mathrm{g}$, Folic Acid $0.201 \mathrm{mg}$, Biotin $0.021 \mathrm{mg}$, Niacin $17 \mathrm{mg}$, Calcium Pantothenate $6 \mathrm{mg}$, Copper $6 \mathrm{mg}$, Cobalt $0.081 \mathrm{mg}$, Iodine $0.81 \mathrm{mg}$, Iron $50 \mathrm{mg}$, Manganese $52 \mathrm{mg}$, Zinc $36 \mathrm{mg}$, Selenium $0.21 \mathrm{mg}$, Choline Chloride (50\%) $300 \mathrm{mg}$, Antioxidant $6 \mathrm{mg}$.

The data obtained were subjected to analysis of variance and in case of a significant effect of the treatments the averages were compared by the SNK test at 5\% probability, using the statistical software SISVAR 5.1. (FERREIRA, 2011).

\section{RESULTS AND DISCUSSION}

Tables 4, 5 and 6 show the results of feed intake ( $\mathrm{kg} / \mathrm{bird})$, weight gain $(\mathrm{kg} / \mathrm{bird})$ and feed conversion ratio $(\mathrm{kg} / \mathrm{kg})$, respectively, for phases $7-$ $21,22-35$ and $36-42$ days of age and total phase of 7 -42 days of age.
For feed consumption (Table 4), with the exception of the 7- to 21-day old phase, the evaluated treatments significantly affected the responses $(\mathrm{P}<0.01)$. The difference in feed consumption between treatments was the result of a reduction in the levels of $\mathrm{ME}, \mathrm{Ca}$ and $\mathrm{aP}$ as a result of the removal of phytase, gum and both ingredients, which were replaced by inert material in the feed mix. The reductions in the average level of ME were $1.60 \% ; 7.60 \%$ and $8.66 \%$ in RN-P treatments (without phytase); RN-G (without gum) and RN-P-G (without phytase and gum), respectively. The reduction in $\mathrm{Ca}$ and aP occurred only in treatments in which phytase was considered in the formulation and removed from the feed, with an average 
reduction of $32.38 \%$ for the Ca level and $19.18 \%$ for the aP, with identical values for the RN-P and RN-P$\mathrm{G}$ treatments, since for the soy gum there was a valorisation only in the energy level.

In the phase from 22 to 35 days of age and in the total period (7 to 42 days) the lowest feed consumption was observed in the RN-P-G treatment (without phytase or gum), which had a greater reduction in energy level $(8.66 \%)$ in response to the lower body weight of these birds, which can also be seen in the lower weight gain of the birds in these phases (Table 5). Smaller birds need less energy, and therefore showed lower feed intake, which demonstrates that a bird's energy need is the sum of the energy requirements for maintenance and weight gain (SAKOMURA, 2004), with maintenance requirements being influenced by the bird's body weight.

In addition to the greater reduction in the level of ME, the RN-P-G treatment also showed a reduction in the level of aP $(32 \%)$, a factor that may also have contributed to a reduction in feed consumption in the growth and total phases. Some studies indicate that the reduction in the level of aP in the feed influences the responses in the different stages of broiler breeding in different ways, and in birds over 42 days of age the reduction has little effect on feed intake (YU et al., 2004). Another determining factor is the level of aP reduction, as smaller reductions (up to $25 \%$ ) do not inhibit food consumption in the growth and final phases (TEIXEIRA et al., 2013).

Table 4. Feed intake $(\mathrm{kg})$ of broilers fed with diets formulated with valuation of the nutritional matrix by phytase and soy gum at each stage of growth.

\begin{tabular}{|c|c|c|c|c|}
\hline \multirow[t]{2}{*}{ Treatments } & \multicolumn{4}{|c|}{ Feed intake (kg/bird) } \\
\hline & 7 to $21 \mathrm{~d}$ & 22 to $35 \mathrm{~d}$ & 36 to $42 \mathrm{~d}$ & 7 to $42 \mathrm{~d}$ \\
\hline $\mathrm{CON}$ & 0.936 & $2.264 \mathrm{a}$ & $1.184 \mathrm{a}$ & $4.384 \mathrm{ab}$ \\
\hline $\mathrm{SN}+\mathrm{P}$ & 0.938 & $2.175 \mathrm{a}$ & $1.136 \mathrm{ab}$ & $4.249 \mathrm{bc}$ \\
\hline RN-P & 0.945 & $2.285 \mathrm{a}$ & $1.143 \mathrm{ab}$ & $4.373 \mathrm{ab}$ \\
\hline $\mathrm{SN}+\mathrm{G}$ & 0.930 & $2.317 \mathrm{a}$ & $1.074 \mathrm{~b}$ & $4.321 \mathrm{~b}$ \\
\hline RN-G & 0.926 & $2.174 \mathrm{a}$ & $1.140 \mathrm{ab}$ & $4.240 \mathrm{bc}$ \\
\hline $\mathrm{SN}+\mathrm{P}+\mathrm{G}$ & 0.969 & $2.339 \mathrm{a}$ & $1.210 \mathrm{a}$ & $4.518 \mathrm{a}$ \\
\hline RN-P-G & 0.909 & $2.005 \mathrm{~b}$ & $1.217 \mathrm{a}$ & $4.131 \mathrm{c}$ \\
\hline$P$-value & 0.2260 & 0.0002 & 0.0046 & 0.0000 \\
\hline SEM & 0.0152 & 0.0453 & 0.0247 & 0.0436 \\
\hline
\end{tabular}

Means with different letters in the same column differ from each other $(\mathrm{p}<0.05)$ by the SNK test

$\mathrm{SEM}=$ Standard error of the mean.

$\mathrm{CON}=$ recommended levels of $\mathrm{ME}, \mathrm{aP}$ and $\mathrm{Ca} ; \mathrm{SN}+\mathrm{P}=$ enhancement of the phytase nutritional matrix and its inclusion; $\mathrm{RN}-\mathrm{P}=$ enhancement of the phytase nutritional matrix, without its inclusion and reduction of $\mathrm{ME}$, aP and $\mathrm{Ca} ; \mathrm{SN}+\mathrm{G}=\mathrm{valorisation}$ of the nutritional matrix of soy gum by its inclusion; $\mathrm{RN}-\mathrm{G}=$ valorisation of the gum's nutritional matrix, without its inclusion and reduction of $\mathrm{ME} ; \mathrm{SN}+\mathrm{P}+\mathrm{G}=$ enhancement of the nutritional matrix of phytase and gum with the inclusion of both; RN-P-G = enhancement of the nutritional matrix of phytase and gum, without including both and with a reduction in $\mathrm{ME}$, aP and $\mathrm{Ca}$.

In the 36- to 42-day-old phase, feed intake in the treatment with the greatest reduction in energy level (RN-P-G) was similar $(\mathrm{P}>0.05)$ to consumption in the other treatments, differing $(\mathrm{P}<0.05)$ only from the treatment with gum $(\mathrm{SN}+\mathrm{G})$; however, this difference did not reflect differences $(\mathrm{P}>0.05)$ in the weight gain between these treatments.

When considering the additive and valuing its (estimated) matrix in the formulation, it was possible to observe the positive effect of the additive. Some studies indicate that the inclusion of phytase promotes improvement due to the increased digestibility and use of nutrients and energy
(JIMENEZ et al., 2019).

For weight gain (Table 5) the effect of the treatments was significant $(\mathrm{P}<0.01)$ in all stages of growth, with stages from 7 to $14 \mathrm{~d}$, from 22 to $35 \mathrm{~d}$ and the total phase clearly showing the lowest gain $(\mathrm{P}<0.05)$ in the treatment with greater reduction in ME (RN-P-G), i.e., in the treatment whose additives (enzyme and emulsifier) were not added to the feed. In the 36 to $42 \mathrm{~d}$ phase, differences $(\mathrm{P}<0.05)$ were seen only between treatments containing the association of the two additives $(\mathrm{SN}+\mathrm{P}+\mathrm{G})$ and treatment without their inclusion (RN-P-G) and with greater reduction in the level of $\mathrm{ME}$ and reduction in the levels of $\mathrm{Ca}$ and $\mathrm{aP}$. 
Table 5. Weight gain $(\mathrm{kg})$ of broilers fed with diets formulated with valuation of the nutritional matrix by phytase and soy gum at each stage of growth.

\begin{tabular}{ccccc}
\hline \multirow{2}{*}{ Treatments } & \multicolumn{4}{c}{ Weight gain (kg/bird) } \\
\cline { 2 - 5 } & 7 to $21 \mathrm{~d}$ & 22 to $35 \mathrm{~d}$ & 36 to $42 \mathrm{~d}$ & 7 to $42 \mathrm{~d}$ \\
\hline $\mathrm{CON}$ & $0.732 \mathrm{a}$ & $1.466 \mathrm{a}$ & $0.779 \mathrm{ab}$ & $2.976 \mathrm{a}$ \\
$\mathrm{SN}+\mathrm{P}$ & $0.741 \mathrm{a}$ & $1.406 \mathrm{ab}$ & $0.805 \mathrm{ab}$ & $2.952 \mathrm{a}$ \\
$\mathrm{RN}-\mathrm{P}$ & $0.706 \mathrm{a}$ & $1.377 \mathrm{~b}$ & $0.789 \mathrm{ab}$ & $2.873 \mathrm{a}$ \\
$\mathrm{SN}+\mathrm{G}$ & $0.730 \mathrm{a}$ & $1.402 \mathrm{ab}$ & $0.777 \mathrm{ab}$ & $2.908 \mathrm{a}$ \\
$\mathrm{RN}-\mathrm{G}$ & $0.704 \mathrm{a}$ & $1.351 \mathrm{~b}$ & $0.783 \mathrm{ab}$ & $2.838 \mathrm{a}$ \\
$\mathrm{SN}+\mathrm{P}+\mathrm{G}$ & $0.736 \mathrm{a}$ & $1.395 \mathrm{ab}$ & $0.847 \mathrm{a}$ & $2.979 \mathrm{a}$ \\
$\mathrm{RN}-\mathrm{P}-\mathrm{G}$ & $0.644 \mathrm{~b}$ & $1.226 \mathrm{c}$ & $0.714 \mathrm{~b}$ & $2.584 \mathrm{~b}$ \\
\hline P-value & 0.0000 & 0.0000 & 0.0101 & 0.0000 \\
SEM & 0.0102 & 0.0209 & 0.0211 & 0.0337 \\
\hline
\end{tabular}

Means with different letters in the same column differ from each other $(\mathrm{p}<0.05)$ by the SNK test.

$\mathrm{SEM}=$ Standard error of the mean.

$\mathrm{CON}=$ recommended levels of $\mathrm{ME}, \mathrm{aP}$ and $\mathrm{Ca} ; \mathrm{SN}+\mathrm{P}=$ enhancement of the phytase nutritional matrix and its inclusion; $\mathrm{RN}-\mathrm{P}=$ enhancement of the phytase nutritional matrix, without its inclusion and reduction of $\mathrm{ME}$, aP and $\mathrm{Ca}$; $\mathrm{SN}+\mathrm{G}=\mathrm{valorisation}$ of the nutritional matrix of soy gum by its inclusion; $\mathrm{RN}-\mathrm{G}=$ valorisation of the gum's nutritional matrix, without its inclusion and reduction of $\mathrm{ME} ; \mathrm{SN}+\mathrm{P}+\mathrm{G}=$ enhancement of the nutritional matrix of phytase and gum with the inclusion of both; RN-P-G = enhancement of the nutritional matrix of phytase and gum, without including both and with a reduction in $\mathrm{ME}$, aP and $\mathrm{Ca}$

The results for weight gain from 22 to 35 days of age show that a reduction in the nutritional levels of $\mathrm{ME}, \mathrm{Ca}$ and aP (without the inclusion of additives) resulted in a reduction in weight gain; however, the inclusion of additives alone or in association promoted a weight gain similar $(\mathrm{P}>$ $0.05)$ to that of the control treatment. This may be indicative of the effect of phytase in contributing to a better digestibility of the nutrients present in the ingredients (MANOBHAVAN, et al., 2015; JIMENEZ et al., 2019) and the emulsifying effect of gum improving lipid digestibility (BORSATTI et al., 2018; VIÑADO et al., 2019).

In the 36- to 42-day-old phase, the treatments with aP levels reduced by $32.38 \%$ (without phytase) showed similar weight gain $(\mathrm{P}>0.05)$ to that of the control treatment, which could be an indication that older birds may be more efficient in using the phytic phosphorus present in vegetables.

For feed conversion ratio (Table 6), statistically significant differences were observed in all phases, thus confirming a behaviour similar to that observed for feed consumption and weight gain. In the total phase from 7 to 21 and from 36 to 42 days of age the highest value of feed conversion (the most unsatisfactory result) was obtained in treatments without the association of enzyme and gum (RN-P-G), the treatment with greatest reductions in energy and in $\mathrm{Ca}$ and $\mathrm{aP}$. Considering the total phase of the study, the most satisfactory result for feed conversion was the treatment containing phytase $(\mathrm{SN}+\mathrm{P})$, showing that the matrix estimated for the phytase enzyme is efficient, and that these nutrients are made available from the feed ingredients to meet the nutritional requirements of broilers (BEESON et al., 2017; JIMENEZ et al., 2019).

The production cost per $\mathrm{kg}$ of live chicken and the gross marketing margin were influenced $(\mathrm{P}<$ 0.05 ) by the treatments (Table 7). The only treatments that promoted a reduction in production costs were the $\mathrm{SN}+\mathrm{P}$ (with phytase) and $\mathrm{RN}-\mathrm{G}$ (without the gum) treatments. In the treatment with phytase the reduction reflected the decrease in the input of dicalcium phosphate and soy oil in the formulations, two high-cost ingredients. In the treatment without soy gum and with a reduction in the energy level, it reflected the effect of reducing the inclusion of soy oil.

Regarding the gross marketing margin, the results show the advantages of valuating the nutritional matrix with phytase $(\mathrm{SN}+\mathrm{P})$ in relation to the standard diet $(\mathrm{CON})$; this did not happen with the valuation of the energy level in the diet by the inclusion of gum $(\mathrm{SN}+\mathrm{G})$, but with diets with reduced energy levels without gum (RN-G). In a way, the inclusion of soy gum led to an increase in the cost per $\mathrm{kg}$ of chicken produced, which influenced a lower gross marketing margin, although this value was similar $(\mathrm{P}>0.05)$ to the control. 
Table 6. Feed conversion ratio $(\mathrm{kg} / \mathrm{kg})$ of broilers fed with diets formulated with valuation of the nutritional matrix by phytase and soy gum at each stage of growth.

\begin{tabular}{ccccc}
\hline \multirow{2}{*}{ Treatments } & \multicolumn{4}{c}{ Feed conversion ratio $(\mathrm{kg} / \mathrm{kg})$} \\
\cline { 2 - 4 } & 7 to $21 \mathrm{~d}$ & 22 to $35 \mathrm{~d}$ & 36 to $42 \mathrm{~d}$ & 7 to $42 \mathrm{~d}$ \\
\hline $\mathrm{CON}$ & $1.279 \mathrm{~b}$ & $1.547 \mathrm{~b}$ & $1.525 \mathrm{~b}$ & $1.473 \mathrm{ab}$ \\
$\mathrm{SN}+\mathrm{P}$ & $1.266 \mathrm{~b}$ & $1.548 \mathrm{~b}$ & $1.413 \mathrm{~b}$ & $1.439 \mathrm{c}$ \\
$\mathrm{RN}-\mathrm{P}$ & $1.337 \mathrm{~b}$ & $1.647 \mathrm{a}$ & $1.468 \mathrm{~b}$ & $1.522 \mathrm{~b}$ \\
$\mathrm{SN}+\mathrm{G}$ & $1.274 \mathrm{~b}$ & $1.654 \mathrm{a}$ & $1.385 \mathrm{~b}$ & $1.486 \mathrm{ab}$ \\
$\mathrm{RN}-\mathrm{G}$ & $1.315 \mathrm{~b}$ & $1.610 \mathrm{a}$ & $1.458 \mathrm{~b}$ & $1.494 \mathrm{ab}$ \\
$\mathrm{SN}+\mathrm{P}+\mathrm{G}$ & $1.317 \mathrm{~b}$ & $1.678 \mathrm{a}$ & $1.430 \mathrm{~b}$ & $1.517 \mathrm{~b}$ \\
$\mathrm{RN}-\mathrm{P}-\mathrm{G}$ & $1.416 \mathrm{a}$ & $1.636 \mathrm{a}$ & $1.707 \mathrm{a}$ & $1.599 \mathrm{a}$ \\
\hline$P$-value & 0.0022 & 0.0322 & 0.0001 & 0.0001 \\
SEM & 0.0241 & 0.0313 & 0.0391 & 0.0182 \\
\hline
\end{tabular}

Means with different letters in the same column differ from each other $(\mathrm{p}<0.05)$ by the SNK test.

$\mathrm{SEM}=$ Standard error of the mean.

$\mathrm{CON}=$ recommended levels of $\mathrm{ME}, \mathrm{aP}$ and $\mathrm{Ca} ; \mathrm{SN}+\mathrm{P}=$ enhancement of the phytase nutritional matrix and its inclusion; $\mathrm{RN}-\mathrm{P}=$ enhancement of the phytase nutritional matrix, without its inclusion and reduction of $\mathrm{ME}$, aP and $\mathrm{Ca} ; \mathrm{SN}+\mathrm{G}=$ valorisation of the nutritional matrix of soy gum and with its inclusion; $\mathrm{RN}-\mathrm{G}=$ valorisation of the gum's nutritional matrix, without its inclusion and reduction of $\mathrm{ME} ; \mathrm{SN}+\mathrm{P}+\mathrm{G}=$ enhancement of the nutritional matrix of phytase and gum with the inclusion of both; RN-P-G = enhancement of the nutritional matrix of phytase and gum, without including both and with a reduction in $\mathrm{ME}$, aP and $\mathrm{Ca}$.

Table 7. Average feed cost of diet, cost per $\mathrm{kg}$ of chicken produced and gross marketing margin for broiler production using diets formulated with valuation of the nutritional matrix by phytase and soy gum.

\begin{tabular}{cccc}
\hline Treatments & Feed cost $(\mathrm{R} \$ / \mathrm{kg})$ & $\begin{array}{c}\text { Cost } / \mathrm{kg} \text { of chickens } \\
(\mathrm{R} \$ / \mathrm{kg})\end{array}$ & Gross marketing margin \\
\hline & 1.406 & $2.069 \mathrm{a}$ & $1.663 \mathrm{~b}$ \\
$\mathrm{CON}$ & 1.353 & $1.948 \mathrm{~b}$ & $1.766 \mathrm{a}$ \\
$\mathrm{SN}+\mathrm{P}$ & 1.346 & $2.049 \mathrm{a}$ & $1.681 \mathrm{~b}$ \\
$\mathrm{RN}-\mathrm{P}$ & 1.373 & $2.041 \mathrm{a}$ & $1.686 \mathrm{~b}$ \\
$\mathrm{SN}+\mathrm{G}$ & 1.296 & $1.935 \mathrm{~b}$ & $1.779 \mathrm{a}$ \\
$\mathrm{RN}-\mathrm{G}$ & 1.323 & $2.006 \mathrm{ab}$ & $1.716 \mathrm{ab}$ \\
$\mathrm{SN}+\mathrm{P}+\mathrm{G}$ & 1.239 & $1.978 \mathrm{ab}$ & $1.740 \mathrm{ab}$ \\
$\mathrm{RN}-\mathrm{P}-\mathrm{G}$ & - & 0.0024 & 0.0017 \\
\hline$P$-value & - & 0.0244 & 0.0202 \\
$\mathrm{SEM}$ & & & \\
\hline
\end{tabular}

Means with different letters in the same column differ from each other $(\mathrm{p}<0.05)$ by the SNK test.

$\mathrm{SEM}=$ Standard error of the mean.

$\mathrm{CON}=$ recommended levels of $\mathrm{ME}, \mathrm{aP}$ and $\mathrm{Ca} ; \mathrm{SN}+\mathrm{P}=$ enhancement of the phytase nutritional matrix and its inclusion; $\mathrm{RN}-\mathrm{P}=$ enhancement of the phytase nutritional matrix, without its inclusion and reduction of $\mathrm{ME}$, aP and $\mathrm{Ca}$; $\mathrm{SN}+\mathrm{G}=\mathrm{valorisation}$ of the nutritional matrix of soy gum and with its inclusion; RN-G = valorisation of the gum's nutritional matrix, without its inclusion and reduction of $\mathrm{ME} ; \mathrm{SN}+\mathrm{P}+\mathrm{G}=$ enhancement of the nutritional matrix of phytase and gum with the inclusion of both; $\mathrm{RN}-\mathrm{P}-\mathrm{G}=$ enhancement of the nutritional matrix of phytase and gum, without including both and with a reduction in $\mathrm{ME}$, aP and $\mathrm{Ca}$.

\section{CONCLUSION}

The inclusion of phytase and soy gum with the individual valuation of the nutritional matrix of each ingredient in the formulation of feed for broiler chickens does not compromise performance from 7 to 42 days of age, but an effect of the association of nutritional matrices was not found. The valuation of the phytase nutritional matrix is economically viable in relation to a standard diet. The economic viability of the valuation of the nutritional matrix with soy gum was not seen, probably due to its high cost in the formulation of diets. Although gum does not compromise zootechnical performance, it does not reduce the cost of production and does not improve the gross margin compared to a standard diet.

\section{REFERENCES}

AKECHI, B. V. Goma de soja na alimentação de frangos de corte: digestibilidade e desempenho. 2015. 43 f. Dissertação (Mestrado em Zootecnia: Área de Concentração em Ciência e Tecnologia 
Animal) - Faculdade de Engenharia, Universidade Estadual Paulista, Ilha Solteira, 2015.

ARAÚJO, J. M. A. Química de alimentos, teoria e prática. 4 ed. Viçosa, MG: Editora UFV, 2008. 596 p.

BEESON, L. A. et al. Hydrolysis of phytate to its lower esters can influence the growth performance nutrient utilization of broilers with regular or super doses of phytase. Poultry Science, 96: 2243-2253, 2017.

BORSATTI, L. et al. Apparent metabolizable energy of by-products from the soybean oil industry for broilers: acidulated soap stock, glycerin, lecithin and their mixture. Poultry Science, 97:1 24-130, 2018

COWIESON, A. J.; WILCOCK, P.; BEDFORD, M. R. Super-dosing effects of phytase in poultry and other monogastrics. World Poultry Science Journal, 67: 225-236, 2011.

EMPRESA BRASILEIRA DE PESQUISA AGROPECUÁRIA- EMBRAPA. Centro de inteligência de aves e suínos - CIAS. ICPFrango/ Embrapa. Disponível em: https://www.embrapa.br/ suinos-e-aves/cias/custos/icpfrango. Acesso em: 22 jul. 2020.

FERREIRA, D. F. Sisvar: a computer statistical analysis system. Ciência e Agrotecnologia, 35: 1039-1042, 2011.

GÁLIK, B. et al. Feed additives affects the nonruminats performace: a review. Animal Physiology, Nutrition and Welfare, 1: 41-47, 2019.

JIMENEZ, H. L. et al. Evaluation of high dietary phytase supplementation on performance, bone mineralization, and apparent ileal digestible energy of growing broilers. Poultry Science, 98: 811-819, 2019.

MANOBHAVAN, M. et al. Effect of super dosing of phytase on growth performance, ileal digestibility and bone characteristics in broilers fed corn-soyabased diets. Journal Animal of Physiology and Animal Nutrition.100: 93-100, 2015.

MELLO, E. S. Variação dos níveis de energia na dieta com goma de soja para poedeiras comerciais, desempenho e digestibilidade. 2017. 45 f. Dissertação (Mestrado em Zootecnia: Área de Concentração em Ciência e Tecnologia Animal) Faculdade de Engenharia, Universidade Estadual Paulista, Ilha Solteira, 2017.
ROSTAGNO, H. S. et al. Tabelas brasileiras para aves e suínos: composição de alimentos e exigências nutricionais. 3. ed. Viçosa, MG: Editora UFV, 2011. $252 \mathrm{p}$.

SAKOMURA, N. K. Modeling energy utilization in broiler breeders, laying hens and broilers. Revista Brasileira de Ciência Avícola, 6: 1-11, 2004.

SOUZA, R. P. P. et al. Use of soybean gum as an emulsifier in diets for commercial laying hens. Pesquisa Agropecuária Brasileira, 54: 683, 2019.

TEIXEIRA, E. N. M. et al. Suplementação da fitase em rações com diferentes níveis de fósforo disponível para frangos de corte. Revista Ciência Agronômica, 44: 390-397, 2013.

TREVISAN, R. B. Programas nutricionais e seu efeito sobre os índices produtivos e econômicos de frangos de corte. 2013. 82 f. Dissertação (Mestrado em Zootecnia: Área de Concentração em Qualidade e Produtividade Animal ) - Faculdade de Zootecnia e Engenharia de Alimentos, Universidades de São Paulo, Pirassununga, 2013.

VIÑADO, A. et al. Crude soybean lecithin as alternative energy source for broiler chicken diets. Poultry Science, 98: 5601-5612, 2019.

WU, D. et al. Comparison of 3 phytases on energy utilization of a nutritionally marginal wheat-soybean meal broiler diet. Poultry Science, 94: 2670-2676, 2015.

YU, B. et al. Exogenous phytase activity in the gastrointestinal tract of broiler chickens. Animal Feed Science and Technology, 117: 295-303, 2004.

ZHANG, B. et al. Effect of fat type and lysophosphatidylcholine addition to broiler diets on performance, apparent digestibility of fatty acids and apparent metabolisable energy content. Feed Science and Technology, 163: 177-184, 2011. 